\title{
BORB, EGY ÚJ TESZTBATTÉRIA A VIZUÁLIS TÁRGYFELISMERÉS ZAVARAINAK VIZSGÁLATÁRA ISMERTETÉS
}

\author{
JUHÁSZ LEVENTE ZSOLT
}

ELTE BTK Pszichológia Doktori Iskola

E-mail: juhaszle@izabell.elte.hu

\begin{abstract}
Az előadás HuMPHREYS és RIDDOCH (1993) által a kutatásokban használt legelterjedtebb eljárásokból összeállitott tesztgyüjteményét (BORB, Birmingham Object Recognition Battery) ismerteti. A teszt a magasabb szintü látás kognitív pszichológiai elméleteiböl kiindulva a tárgyfelismerést több szakaszból álló folyamatnak tekinti. A vizuális feldolgozás különbözö stádiumaiban sérülhet, így a tárgyazonositás zavarának (agnóziának) különböző típusai különböztethetők meg, finomítható a klasszikusnak számító apperceptív és asszociatív felosztás. Ezek elkülönitésére alkalmas a szerzök által alkotott tesztbattéria, amely a klinikai diagnosztikában dolgozók számára is könnyen elsajátítható, és megkönnyítheti a klinikus dolgát a megfelelő rehabilitációs munka kidolgozásában. A tanulmány bemutatja az egyes feladattípusokat és az eredmények interpretálásának lehetöségeit is.
\end{abstract}

Kulcsszavak: Kognitív neuropszichológia, vizuális tárgyfelismerés, agnózia, neuropszichológiai diagnosztika

A kognitív neuropszichológiai megközelítés sajátos ötvözete az elméleti, az elsősorban alapkutatásokkal foglalkozó általános lélektani és a gyakorlati, klinikai lélektani felfogásoknak. A kognitív neuropszichológiával foglalkozók elméleteiket, modelljeiket, sőt módszereiket is igen szívesen kölcsönzik a kognitív pszichológiától, melynek művelői elsősorban a normál emberi pszichikus működések funkcionális szintű leírására törekszenek. Ezek a modellek aztán kiválóan alkalmasak lehetnek a szerzett vagy fejlődési kognitív működés zavarok leírására, értelmezésére. Sok esetben ez a viszony (mármint az ötlet- és információáramlás) nem egyirányú, hanem a zavart működések vizsgálata alapján a normális működésekről is fontos elképzeléseket lehet alkotni, amelyeket az általános lélektan a maga módszereivel tovább vizsgálhat. Ugyanígy a klinikai neuropszichológia elvei és módszerei, mint például az eset vagy szindróma alapú megközelítés, a kettős disszociá- 
ció elve, a tesztmódszer is fontos jellemzői a kognitív neuropszichológiai elméletképzésnek és módszertannak. E kettős kötödés és eredet megtermékenyítően hat az új diagnosztikai eszközök fejlesztésére is. Az utóbbi évtizedben számos olyan teszt és feladat jelent meg a szakirodalomban (majd kis késéssel a pszichodiagnosztikai eszközök piacán is), amely tesztben az alkotók valamely pszichés múködés általános lélektani modelljéből indulnak ki, és a próbák során e modell komponenseit vizsgálják, vagyis azt, hogy az adott feltételezett összetevőnek megfelelő mentális működés ép-e vagy sérült a vizsgált betegnél. E szerzők általában az eszközök ökológiai validitására, vagyis az „életszerűségre” is törekedtek. Ezek a tesztek elősegíthetik a sérülés természetének alaposabb felderítését, és ez alapján egy célzottabb rehabilitációs terv, terápiás rezsim kialakítását. Az én célom a RIVERMEAD emlékezeti teszthez hasonlóan „elméletvezérelt” neuropszichológiai tesztcsomag bemutatása, amellyel a látás, ezen belül is elsősorban a tárgyfelismeréssel kapcsolatos részfunkciók vizsgálhatók.

A tesztsorozat alkotói M. Jane Riddoch és Glyn W. Humphreys a birminghami egyetem pszichológusai, neves látáskutatók. A Battéria feladatait saját és mások neuropszichológiai vizsgálatai alapján alakították ki. A teszt alapjául szolgáló munkaelmélet kialakításában figyelembe vették a kognitív idegtudományok legmodernebb, látással kapcsolatos elméleteit. A teszt fó előfeltevése: A tárgyfelismerés több szakaszra bontható.

A szakaszolhatóság melletti egyik fő empirikus érv éppen a neuropszichológiai vizsgálatokból származik, nevezetesen a vizuális agnóziák jelensége (FARAH, 1990). A klasszikus klinikai neuropszichológia meghatározása szerint az agnózia a tárgyfelismerés és az alakazonosítás zavara, de ez a probléma nem tulajdonítható az intellektus általános leépültségének, figyelmi zavarnak, nyelvi sérülésnek vagy az alapvető szenzoros müködések sérülésének (PÉTER, 1986). Többféle modalitásban előfordul; a vizuális mellett van akusztikus (MENDEZ, GEEHAN, 1988), taktilis formája is (REED, CASELLI, 1994), néhányan színagnóziának nevezik a színek megnevezésének képtelenségét (KInSBOURNE, WARRINGTON, 1964; ZEKI, 1990). A betegeknél a sérülés általában csak egyetlen modalitásra szorítkozik, a többiben a felismerés ép. A klinikai szóhasználatban máig bevett a LISSAUER (1890) által bevezetett apperceptív és asszociatív vizuális agnóziák megkülönböztetése. Eszerint az apperceptív forma esetén a tárgyfelismerést az inger alapján felépülő belső reprezentációk (perceptum) létrehozásának zavara akadályozza meg. Míg az asszociatív forma esetén a belső perceptuális reprezentációk létrejönnek, de ezek nem kapcsolhatók, nem vethetők össze az emlékezetben tárolt tudással, tehát a reprezentációkon keresztül nem érhető el a tárggyal kapcsolatos perceptuális és szemantikai tapasztalat. Külsőleg hasonló viselkedést (tárgymegnevezési zavart) mutatnak, egy másik vizuális modalitásra vonatkozó zavarban, az optikus afáziában szenvedő betegek. De náluk nem a tárgyfelismerés sérült, hanem a névinformáció előhívása az emlékezetből. Ekkor a beteg a megnevezési zavar ellenére a tárgyhoz tartozó funkcionális és perceptuális tudást képes előhívni, felhasználni (például a tárgy használatát mímelni, a méretére vonatkozóan adekvát becsléseket tenni). A klini- 
kai gyakorlatban apperceptív agnóziásnak tekintik a pácienst, ha ép alapvető látási funkciók ellenére sem képes másolni vagy a tárgyakat részekből összerakni, vagy azokat párosítani. Asszociatív agnóziában szenvedóknek ezek a feladatok mennek, de ilyenkor a tárgyhoz kapcsolódó tudás nem mozgósítódik (a tárgy megjelenésével és funkciójával kapcsolatos feladatokban rosszul teljesít). A Lissauer-féle kettős felosztás ma is elfogadott, habár érvényességét sokan vitatják (ZEKI, 1993). Egyrészt sokan azt állítják, hogy asszociatív agnózia esetén is kimutatható perceptuális sérülés (FARAH, 1999a; 1999b; LAWSON, HUMPHREYS, 1998), másrészt a kettős felosztás nem ad elég lehetőséget a folyamatok finomabb felderítésére.

WARRINGTON és TAYLOR (1978) dolgozott ki először egy már részletesebb és igazán kognitív neuropszichológiai modellt a tárgyfelismerésről, amelynek összetevői:

$$
\begin{aligned}
\text { kép } & \rightarrow \text { ALAK KÓDOLÁS } \rightarrow \text { FIGURA HÁTTÉR SZEGMENTÁCIÓ } \rightarrow \\
& \rightarrow \text { PERCEPTUÁLIS KATEGORIZÁCIÓ } \rightarrow \text { SZEMANTIKUS OSZTÁLYOZÁS }
\end{aligned}
$$

Warrington szerint az első két stádium (összefoglaló néven a VIZUÁLIS ANALÍZIS részei) az alacsony szintű perceptuális folyamatokhoz tartozik, és ezek sérülése a szintén tárgyfelismerési zavarhoz vezető pszeudoagnóziát okozza. A következő szakasz a PERCEPTUÁLIS KATEGORIZÁCIÓ, amely azokat a folyamatokat jelöli, amelyek lehetővé teszik az alakkonstanciák vagy tárgykonstanciák (annak felismerése, hogy a tárgy különböző nézetei egyazon tárgyhoz tartoznak) létrejöttét. Ennek (jobb féltekéhez lokalizált) sérülése okozza az apperceptív agnóziát. Bal poszterior sérülés esetén mutatható ki az utolsó szakasz, az észlelethez történő jelentéstulajdonítás kiesése (asszociatív agnózia).

HuMPHREYS és RIDDOCH (1987a; 1987b; 1994) elvetik a pszeudoagnózia fogalmát, szerintük az nem magyarázó értékű. Ők inkább az apperceptív agnóziák altípusait különböztették meg. Szerintük a forma-diszkrimináció sérülése is agnózia, amelyet ők formaagnóziának (alakagnóziának) neveztek. Az alakkonstancia folyamatai, amelyek lehetővé teszik egy tárgy különböző nézeteinek párosítását, illesztését, nem függetlenek az alacsonyabb folyamatoktól, amelyek a formapercepcióban vesznek részt. Transzformációs agnóziának nevezik azt a jelenséget, ha a sérült képes a tárgyak prototipikus / kanonikus (legjellemzőbb) nézetének azonosítására, de perspektivikus rövidülésben és jellemző tulajdonságai takarása esetén azokat nem ismeri föl (lásd a WARRINGTON és TAYLOR által 1978-ban leírt jelenséget). Vagyis a nézőközpontú reprezentációkból (a MARR, 1982 által 2 és 1/2 dimenziósnak nevezett reprezentáció) nem tudnak létrejönni a tárgyközpontú reprezentációk (a 3 dimenziós tárgyreprezentációk), tehát az LTM-ben tárolt tárgyreprezentációk (strukturális leírások) nem elérhetők. A mai elképzelések (például FARAH, 1999b) szerint viszont a nézőpontfüggetlen reprezentáció kialakulása nem szükséges a tárgyfelismeréshez, az a nézőpontfüggő információkon keresztül is lehetséges. Magában az alakkonstancia kialakulásában tehát két párhuzamos folyamatot feltételeznek, az egyik az, amelyik a tárgy jellegzetes vonásainak kiemelésén alapul, a másik pedig az alakzathoz a fő tengely hozzárendelését kívánja meg, és a feldolgozás a tárgy részeinek ehhez a tengelyhez való viszonyát veszi alapul (MARR, 1982; magyarul KovÁCS, 1991). 
Az olyan esetet, ahol a beteg a tárgyat látva annak egyes részeit képes volt megnevezni, de magát a tárgyat nem, integrációs agnóziának nevezték (HUMPHREYS, HidDOCH [1987a] H. J. A. monogramú betegét, ha ezt a megkülönböztetést nem tették volna meg, kiváló másolási képességei miatt asszociatív agnóziásnak kellett volna osztályozni, pedig nyilvánvalóan problematikus volt nála a perceptuális reprezentációk létrehozása). A formaagnózia a globális formát meghatározó perceptuális folyamat sérülését jelenti, míg az integrációs agnózia az inger által tartalmazott lokális vonások feldolgozásának, majd ezt követő integrációjának zavarait implikálja. Szemantikus hozzáférés agnóziának nevezik az olyan eseteket, ahol a tárgyfelismerés rossz, és funkcióleírás (például: Mire használjuk?) alapján képtelenek a tárgyakat megnevezni.

A szerzők mindezekeket a megkülönböztetéseket beépítették a teszt alapjául szolgáló feltételezett tárgyfelismerési modellbe (RIDDOCH, HUMPHREYS, 1993):

2-5. teszt

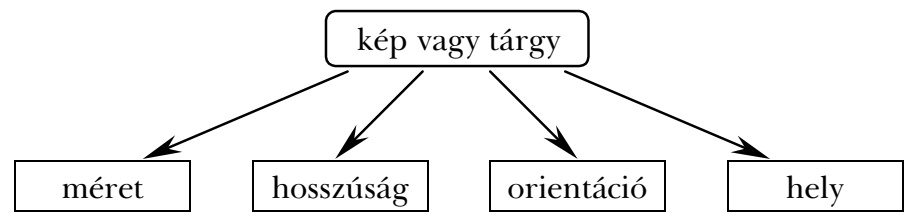

6. teszt

7., 8. teszt

9., 10. teszt

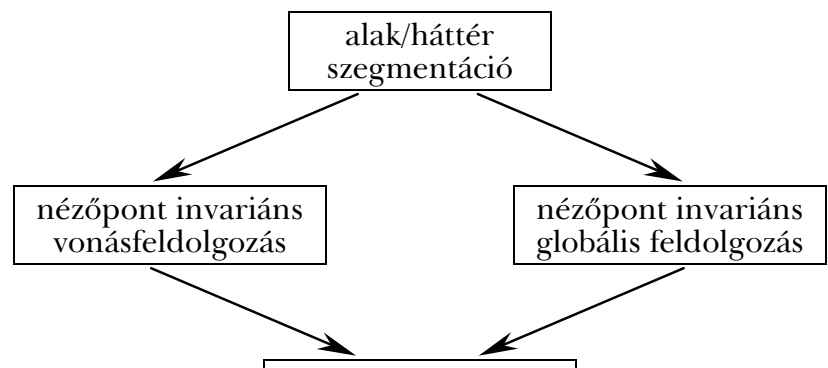

9., 10. teszt

11., 12. teszt

13., 14. teszt

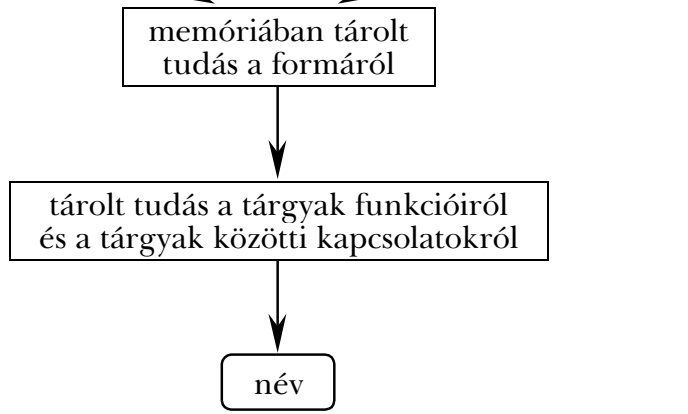

1. ábra. A tárgyfelismerés modellje a BORB tesztben 


\section{A BORB (BIRMINGHAM OBJECT RECOGNITION BATTERY) ISMERTETÉSE}

A tesztbattéria 14 altesztből áll, amelyek a tárgyfelismerés különböző stádiumait vizsgálják. A szerzők megtartották a Lissauer-féle apperceptív vs. asszociatív agnózia felosztást: a perceptuális reprezentáció kialakulását vizsgáló feladatokat a prekategoriális vizuális feldolgozás tesztjeinek, míg a jelentésadással kapcsolatos próbákat a tárolt tudás elérése tesztjeinek nevezik.

\section{Prekategoriális tesztek}

1. Másolás

2. Hosszúságillesztés

3. Méretillesztés

4. Orientációillesztés
5. Hiánypozíció-illesztés

6. Beágyazott (átfedő) ábrák

7. Minimális vonás

8. Rövidült nézet

\section{Másolásteszt}

Ez a bevezető teszt. A feladatban egyszerűbb és komplexebb síkbeli és térbeli alakzatokat kell lerajzolni. Az eljárás alkalmas a vizuo-motoros koordináció, az alapvető vonások észlelése, figyelemváltás, alak-háttér szegmentáció képességének vizsgálatára. Gyenge teljesítmény az alábbi sérülések esetén fordul elő: apperceptív agnózia különböző formái, féloldali neglect, konstrukciós diszpraxia, de e két utóbbi sérülésben szenvedő beteg a motoros teljesítményt nem kívánó többi feladatban általában megfelelően teljesít.
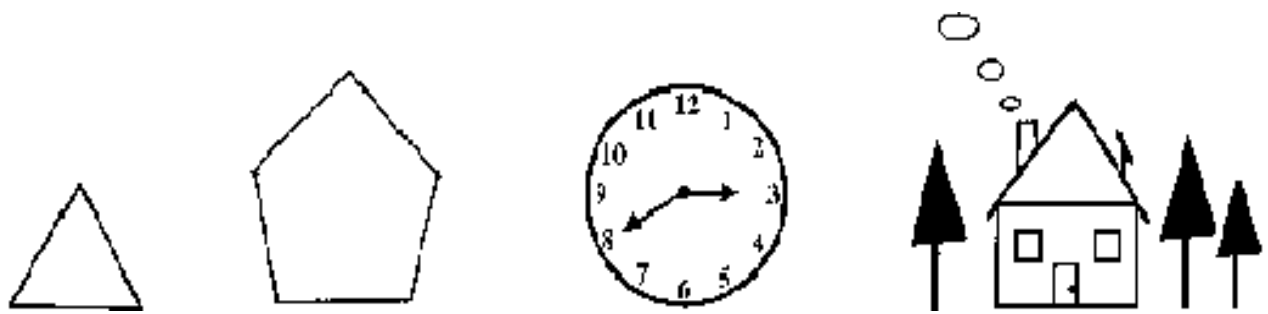

2. ábra. BORB 1. feladat. Példák a lemásolandó ábrákból

\section{Hosszúságillesztés-teszt}

A feladat által vizsgált képesség: a hosszúságtulajdonság észlelése. Ebben a feladatban a vizsgált személy a tesztlapon vonalpárokat lát egymás mellett. Bizonyos vonalpárok egyenlő hosszúságúak, míg mások kissé, de észrevehetően különböznek. 
A feladat: az ingerpárok közül az azonos hosszúságúakat kell kiválasztani. Teljesítménydeficit elsősorban apperceptív formaagnózia estén fordul elö. Csoportos vizsgálatok alapján a jobb félteke sérültek teljesítménye rosszabb (WARRINGTON, RABIN, 1970).

\section{Méretillesztésteszt}

Ez a próba a mérettulajdonság észlelésének képességét vizsgálja. Ebben a feladatban a vizsgált személy körpárokat lát, amelyek átmérője egyenlő vagy kissé (de észrevehetően) eltérő. A feladat: az ingerpárok (körpárok) közül az azonos nagyságúakat kell kiválasztani. Sérülés leginkább apperceptív formaagnózia esetén. A jobb félteke sérültek teljesítménye rendre rosszabb (WARRINGTON, RABIN, 1970).

\section{Orientációillesztés-feladat}

A teszt által megcélzott képesség az iránytulajdonság észlelése. A vizsgált személy vonalpárokat lát, amelyek párhuzamosak vagy kissé (de észrevehetően) elhajolnak egymástól. A feladat: az ingerpárok (vonalpárok) közül az azonos irányúakat kell kiválasztani. Deficit főleg apperceptív formaagnózia esetén fordul elő. Egyértelmű lateralizáció nem mutatható ki a sérülés helye tekintetében (RIDDOCH, HUMPHREYS, 1993).

\section{Hiánypozícióillesztés-teszt}

A feladat a lokalizáció, a helytulajdonság észlelését vizsgálja. A vizsgált személy két kört lát, amelyek mindegyikéből hiányzik egy-egy rövid szakasz. Az ingerpárok (két csonka kör) közül azokat kell kiválasztani, amelyek megegyező részén van a rés. Az apperceptív formaagnóziások teljesítménye általában rossz. Neurológiai sérültek közül a jobb félteke károsodottak teljesítménye rosszabb.
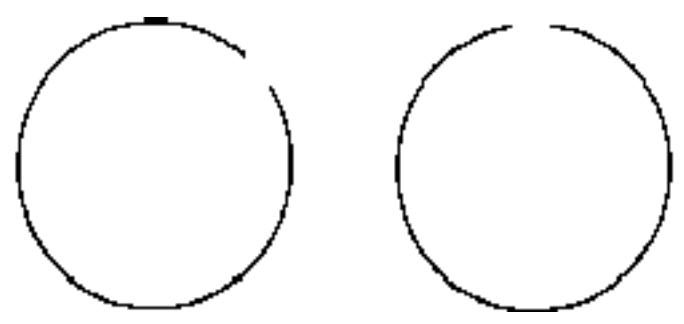

3. ábra. BORB 5. feladat: hiánypozíció-illesztés Egy nem illeszkedő ingerpár 


\section{Beágyazott (átfedö) ábrák feladat}

Az alak-háttér szegmentációt vizsgáló feladat. Az egymást átfedő alakzatokat (betűk, geometriai formák, tárgyak) kell egyenként megnevezni. E próbában romlott teljesítmény mutatnak az apperceptív formaagnóziában, az unilaterális neglectben, a Bálint-szindrómában (szimultán agnózia) szenvedők, de e két utóbbi kórforma az agnóziától megkülönböztethető, mert ez utóbbi sérültek nem csak az átfedő ábrák feladatban tévesztenek. A BORB-csomagban elhelyezett változat afáziás betegekkel is elvégezhető.
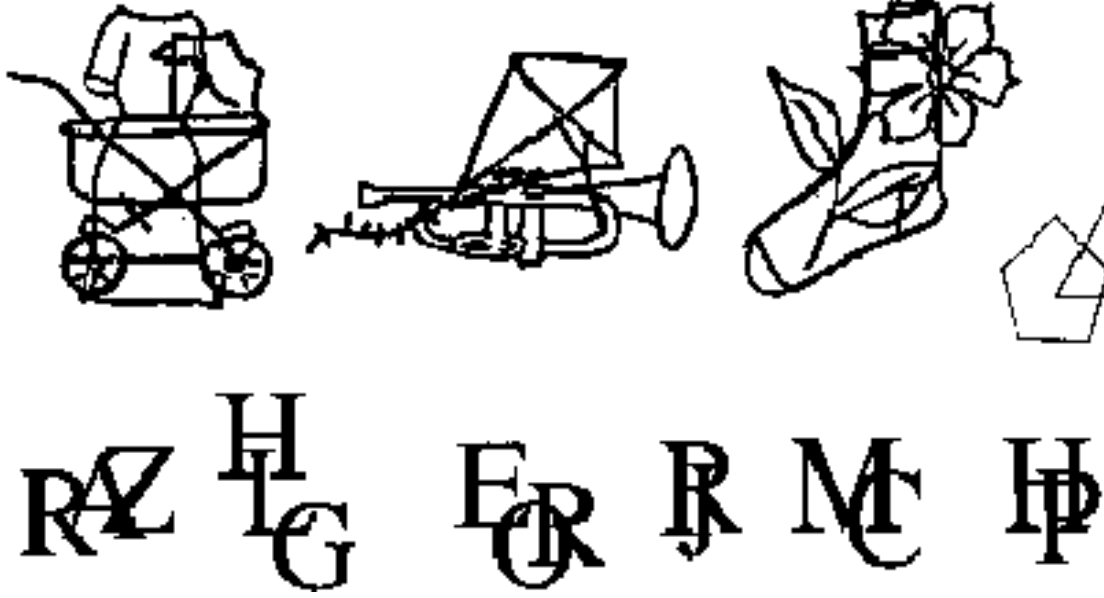

4. ábra. BORB 6. feladat: beágyazott ábrák. Néhány ábra a feladatból

\section{Minimális vonás feladat}

Ez a feladat azt vizsgálja, hogy a lokális (jellemző) vonások feldolgozásán alapuló tárgykonstancia lehetôségének lecsökkentése hogyan befolyásolja a felismerés képességét. A feladatban három ábrát lát a személy, amelyek közül kettő azonos tárgyat ábrázol, csak más nézőpontból látszanak (kanonikus és szokatlan nézet). A harmadik ábra az ingerábrához vizuálisan hasonló, de különböző tárgyat ábrázol. Ki kell választani a kanonikus tárggyal (ingerábra) egyezőt a tesztingerek közül. A szokatlan nézetben a tárgy valamely jellemző tulajdonsága nem látszik. Teljesítménydeficit esetén appercepciós transzformációs agnóziáról beszélhetünk, valószínủleg a tárgy jellemző részeinek takartsága esetén a holisztikusabb, tengely-hozzárendelést igénylő stratégia nem elégséges az alakkonstancia kialakításához. Neurológiai betegek csoportos vizsgálatakor nem találtak különbséget a bal és jobb oldali félteke sérültek között (RIDDOCH, HuMPHREYS, 1993). 


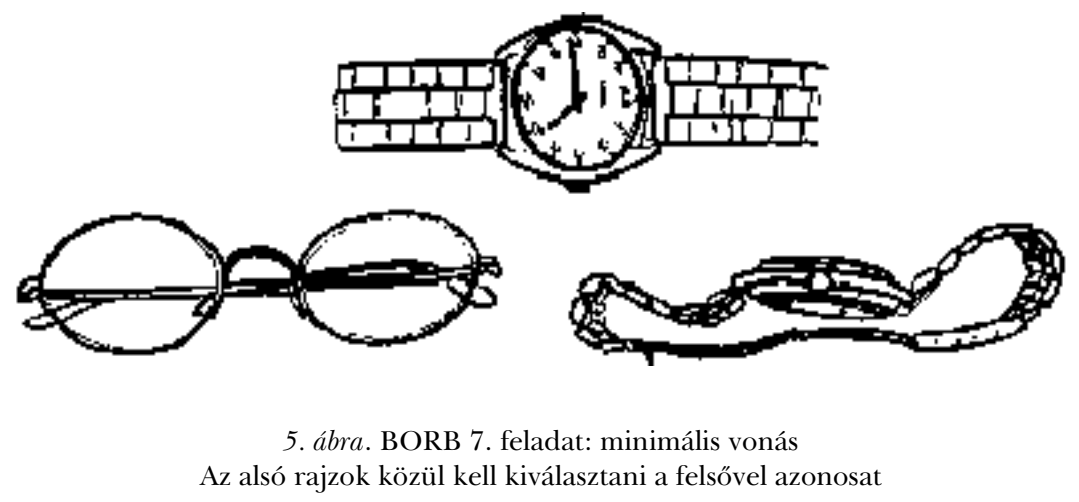

\section{Rövidült nézet feladat}

A feladat azt vizsgálja, hogy az alakkonstanciát a tárgy fó tengelyének kiemelésén keresztül elérő vizuális feldolgozás lehetőségének lecsökkentése miképpen befolyásolja a tárgy azonosítását. A feladatban az előzőhöz hasonlóan három ábra van, melyek közül kettő azonos, csak más nézőpontból látszik (kanonikus és szokatlan nézet). Ki kell választani a kanonikus tárggyal (ingerábra) egyezőt a tesztingerek közül. A szokatlan nézetben a tárgy rövidülésben (a tengely-információ hiányzik) látszik. A sérülés típusa appercepciós transzformációs agnózia, vagyis a beteg egyedül a lokálisabb feldolgozás alapján nem képes az alakkonstanciát kialakítani. Betegcsoportok vizsgálatakor nem találtak különbséget a bal és jobb félteke sérültek között (RIDDOCH, HUMPHREYS, 1993).

Újabb elképzelések (például FARAH, 1999a) szerint az alakkonstancia elérése nem feltétele a tárgyfelismerésnek, azt inkább egyfajta vizuális problémamegoldásnak tekintik.
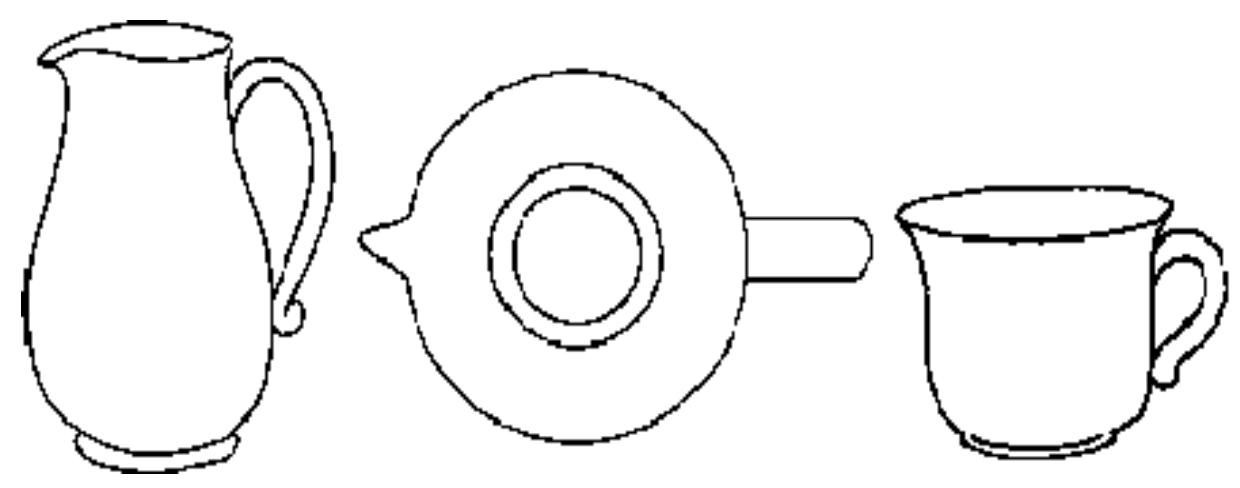

6. ábra. BORB 8. feladat: rövidült nézet Az első rajzhoz kell az azonosat megtalálni 


\section{Az emlékezetben tárolt tudás elérését vizsgáló feladatok}

9. Rajzolás emlékezetből

10. Tárgydöntés

11. Itemillesztés
12. Asszociációs illesztés

13. Képmegnevezés (rövid)

14. Képmegnevezés (hosszú)

\section{Rajzolás emlékezetból feladat}

A próba a vizuális LTM épségét és a vizualizációt (képzeletet) vizsgálja. A vizsgált személynek egy háromszöget, egy órát, egy virágot, egy zsiráfot, egy kengurut és egy tigrist kell emlékezetből lerajzolnia.

A vizuális emlékezet sérült, ha a páciens nem megfelelő részeket rajzol be, főleg az élő kategóriában (RIDDOCH, HumPhreYs, 1992; WARRINGTON, SHALLICE, 1984). A vizualizáció sérült, ha a beteg jellemzően mind az állatok, mind a tárgyak egyes részeit, elemeit hagyja el. Mindkét sérülés előfordulhat asszociatív agnóziában. Egyoldali neglect esetén szintén gyenge a teljesítmény, de ekkor a másolás is rossz volt, főleg az kontralaterás oldalon (elhagyások). Diszpraxiás beteg esetén szintén gyenge a teljesítmény, de az ő másolása is rossz, nem mutat az agnózia esetén kimutatható kategóriahatást.

\section{Tárgydöntés feladat}

Az emlékezetben tárolt vizuális információk épségét vizsgálja a feladat, és azt, hogy ezeket miképpen képes összehasonlítani a beteg az ingerről kialakított reprezentációkkal. A feladatban egyetlen ábrát mutatnak a személynek, akinek el kell döntenie, hogy létezik-e az ábrázolt tárgy?

Asszociatív szemantikus hozzáférés agnózia esetén a teljesítmény romlik, ilyenkor rendszerint az emlékezetből való rajzolás is sérült. Gyakran találhatunk kategóriaspecifikus hatásokat, ugyanis az élőlényekkel kapcsolatos döntések nehezebbek. A bal félteke sérülteknél gyakoribb a rontás.
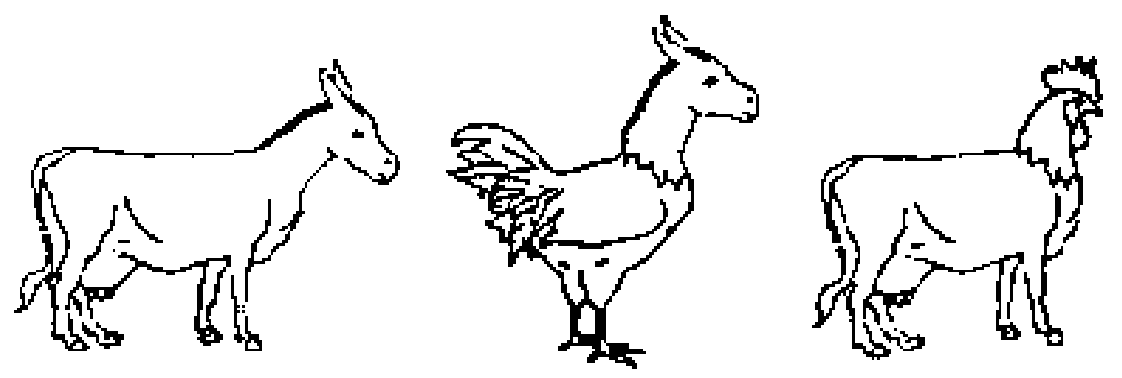

7. ábra. BORB 10. feladat: tárgydöntés. Néhány nem létező tárgy 


\section{Itemillesztés feladat}

A feladat azt vizsgálja, hogy a páciens képes-e mozgósítani a tárgyakhoz kapcsolódó szemantikai és funkcionális tudást, épek-e ezek a tárolt információk. A beteg három ábrát lát, egy ingerábrát és két célingert. Ez utóbbiak közül az egyik azonos az ingerábrán bemutatottal, csak annak egy másik példánya. Az ingerábrához kell kiválasztani azt a tárgyat, ami az előbbivel azonos kategóriába tartozik (ugyanaz a neve).

Sérülés: asszociatív szemantikai hozzáférés agnózia (ha az apperceptív forma ki lett zárva). Teljesítménycsökkenés előfordulása főleg bal poszterior sérülés esetén.

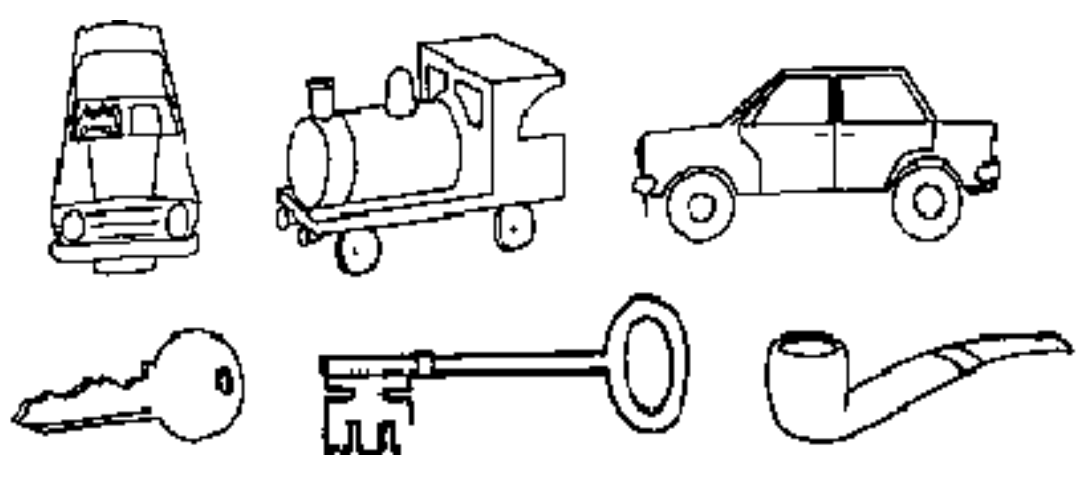

8. ábra. BORB 11. feladat: itemillesztés

Minden sorban az első rajzhoz kell kiválasztani kategóriájának egy másik példányát

\section{Asszociatív illesztés feladat}

A feladat azt vizsgálja, hogy a páciens hozzáfér-e tárgyakhoz kapcsolódó szemantikai és funkcionális tudáshoz, és épek-e ezek a tárolt információk.

A feladat elrendezése hasonló az előzőhöz, itt az ingerképpel asszociatív módon összetartozó ábrát kell kiválasztani a két vizuálisan hasonló ábrából.

Teljesítménydeficit főleg asszociatív szemantikus hozzáférés agnózia esetén, gyakoribb bal oldali lézió esetén. 

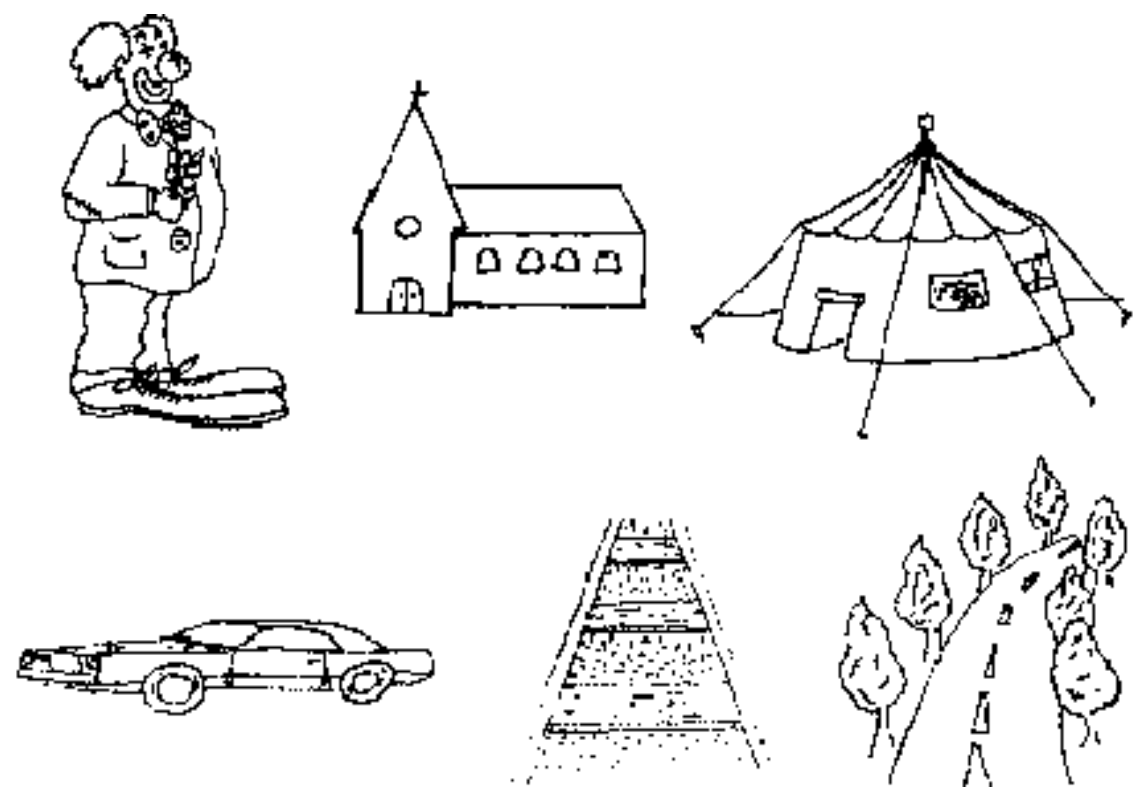

9. ábra. BORB 12. feladat: asszociatív illesztés

Az első rajzhoz kell kiválasztani a vele szoros asszociatív kapcsolatban állót

\section{Képmegnevezési feladat (rövidebb változat)}

A feladat azt vizsgálja, hogy képes-e a személy a tárgyhoz tartozó perceptuális és szemantikai információk alapján a tárgyhoz tartozó névinformációt is elérni. A feladatban 15 tárgy (élőlények) rajzát mutatjuk be, a betegnek meg kell azokat nevezni. Ezek olyan élőlények, melyek szógyakorisága relatíve alacsony, ezért a feladat viszonylag nehéz. Megnevezési problémák esetén asszociatív szemantikus hozzáférés agnóziáról beszélhetünk, ha a battéria megelőző feladataiban is rossz teljesítményt mutat a sérült. Optikus afázia vagy amnesztikus afázia valószínűbb, ha a beteg a teszt többi feladatában jól teljesít.

\section{Képmegnevezési feladat (hosszabb változat)}

Az előzőhöz hasonlóan ez a feladat is azt vizsgálja, hogy képes-e a személy a tárgyhoz tartozó perceptuális és szemantikai információk alapján a tárgyhoz tartozó névinformációt is elérni. A feladatban tárgyak (76 darab) rajzát mutatjuk be, a betegnek meg kell azokat nevezni. 
Az ingerek egyik fele strukturálisan hasonló, míg másik fele vizuálisan különböző elemekből áll. A teszt elemei csoportosíthatók szógyakoriság alapján is; fele a magas, másik fele az alacsony frekvenciájú csoportba tartozik.

Ha teljesítményromlás fóleg a strukturálisan hasonló elemek esetén fordul elő, ekkor feltételezhető a vizuális feldolgozási deficit (vagyis az apperceptív vizuális agnózia), és ez más feladatokban is jelentkezik. Ha főleg ritkább nevek esetén van deficit, akkor valószínűleg szóhozzáférési problémáról, anómiáról lehet szó, főleg ha a beteg a teszt többi feladatában jól teljesített.

Talán ebből a rövid ismertetésből is kiderült, hogy a BORB valóban lehetőséget ad a tárgyfelismerési zavarok kifinomultabb vizsgálatára. A szerzők minden egyes feladatot világos, követhető instrukcióval láttak el. A kvantifikálható feladatoknál a normál és sérült populációkra jellemző közép- és szórásértékeket is megtaláljuk, amelyek megkönnyítik a teszteredmények interpretálását. A teszt felvétele, kiértékelése könnyen elsajátítható, speciális tréninget nem igényel. A teszt viszonylagos információgazdagságának sajnos ára van, a tesztfelvételhez szükséges idő megnövekedése, mivel minden feladat több tételből áll. Ezért új betegeknél érdemes - a szerzők által is ajánlott - a teszt feladataiból összeállítható „szűrőtesztet” felvenni, amely nagyobb léptékủ értékelésre ad lehetőséget, s amelyre alapozva aztán a célzottabb vizsgálatokhoz szükséges feladatatok kiválaszthatók a gyüjteményből.

A BORB elterjedése esetén - a RIVERMEAD-hez hasonlóan - a hazai neuropszichológiai diagnosztika hasznos eszköze lehet.

\section{IRODALOM}

FARAH, M. (1990) Visual Agnosia. MIT Press, Cambridge

FARAH, M. (1999a) Relations among the agnosias. In Humphreys, G. W. (ed.) Case Studies in the Neuropsychology of Vision. Psychology Press, Hove

FARAH, M. (1999b) The Cognitive Neuroscience of Vision. Blackwell, Oxford

Humphreys, G. W., Riddoch, M. J. (1987a) To See But Not to See: A Case of Visual Agnosia. LEA, London

Humphreys, G., W., Riddoch, M. J. (1987b) The fractionation of visual agnosia. In Humphreys, G. W., Riddoch, M. J. (eds) Visual Object Processing: A Cognitive Neuropsychological Approach. LEA, London

Humphreys, G., W., Riddoch, M. J., Donnelly, N., Freeman, T. A. C., Boucart, M., MülLER, H. M. (1994) Intermediate visual processing and visual agnosia. In Farah, M., Ratcliff, G. (eds) The neuropsychology of high-level vision. LEA, Hillsdale

Kinsbourne M., WARrington, E. K. (1964) Observations on colour agnosia. Journal of Neurology, Neurosurgery and Psychiatry, 27, 296-299.

KovÁcs I. (1991) Egy tudományos vízió. Pszichológia, 11, 77-126.

Lawson, R., Humphreys, G. W. (1998) The neuropsychology of visual object constancy. In Walsh, V., Kulikowski, J. (eds) Perceptual constancy. Why things look as they do. Cambridge University Press, Cambridge 
Lissauer, H. (1890) Ein Fall von Seelenblindheit nebst einem Beitrage zur Theorie derselben. Archiv für Psychiatrie und Nervenkrankheiten, 21, 222-270.

MARR, D. (1982) Vision. W. H. Freeman, San Francisco

Mendez, M. F., Geehan, G. R., (1988) Cortical auditory disorders: Clinical and acoustic features. Journal of Neurology, Neurosurgery and Psychiatry, 51, 1-9.

PÉTer Á. (1986) Neurológia. Neuropszichológia. Tankönyvkiadó, Budapest

Reed, C. L., Caselli, R. J. (1994) The nature of tactile agnosia: A case study. 32, 527-539.

Riddoch, M. J., Humphreys, G. W. (1992) The smilling giraffe: An illustration of a visual memory disorder. In R. Campbell (ed.) Mental Lives. 82-93. Basil Blackwell, Oxford

Riddoch, M. J., Humphreys, G. W. (1993) BORB. Birmingham Object Recognition Battery. LEA, Hove

Warrington, E. K., Shallice, T. (1984) Category-specific semantic impairments. Brain, $107,829-854$

WARrington, E. K., RAbin, P. (1970) Perceptual matching in patients with cerebral lesions. Neuropsychologia, 8, 475-487.

WARrington, E. K., TAYlor, A. M. (1978) Two categorical stages of object recognition. Perception, 695-705.

ZEki S. (1990) A century of cerebral achromatopsia. Brain, 113, 1721-1777.

ZEKI S. (1993) A vision of the brain. Blackwell Scientific Publications, Oxford

\title{
BORB - A NEW TEST BATTERY \\ FOR VISUAL OBJECT RECOGNITION DISORDERS
}

\author{
JUHÁSZ, LEVENTE ZSOLT
}

This article introduces a test battery (BORB, Birmingham Object Recognition Battery) constructed from methods used in research by M. J. RIDDOCH and G. W. HUMPHREYS (1993). On the basis of cognitive psychological theories of high-level vision the tests presume that the process of the object recognition comprises several stages. The visual processing may be damaged in these stages, so different types of disturbance of the object identification (agnosia) can be differentiated. This improves the classical apperceptive vs. associative division originated from LISSAUER (1890). This battery is capable of discriminating of these types and the use can be attained easily by the clinical staff and may make their rehabilitational work easier. The article presents the types of probes and the possibilities of their interpretation.

Key words: cognitive neuropsychology, visual object recognition, agnosia, neuropsychological diagnosis 